\title{
ANALYSIS OF EXTREME HYDROLOGICAL EVENTS ON THE DANUBE USING THE PEAK OVER THRESHOLD METHOD
}

\author{
VERONIKA BAČOVÁ-MITKOVÁ, MILAN ONDERKA
}

Institute of Hydrology SAS, Račianska 75, 83102 Bratislava 3, Slovakia; Mailto: mitkova@uh.savba.sk

The Peak Over Threshold Method (POT) was used as an alternative technique to the traditional analysis of annual discharge maxima of the Danube River. The POT method was applied to a time-series of daily discharge values covering a period of 60 years (1931-1990) at the following gauge stations: Achleiten, Kienstock, Wien, Bratislava and Nagymaros. The first part of the paper presents the use of the POT method and how it was applied to daily discharges. All mean daily discharges exceeding a defined threshold were considered in the POT analysis. Based on the POT waves independence criteria the maximum daily discharge data were selected. Two theoretical log-normal (LN) and Log-Pearson III (LP3) distributions were used to calculate the probability of exceeding annual maximum discharges. Performance of the POT method was compared to the theoretical distributions (LN, LP3). The influence of the data series length on the estimation of the $N$-year discharges by POT method was carried out too. Therefore, with regard to later regulations along the Danube channel bank the 40, 20 and 10-year time data series were chosen in early of the 60-year period and second analysed time data series were selected from the end of the 60-year period. Our results suggest that the POT method can provide adequate and comparable estimates of $N$-year discharges for more stations with short temporal coverage.

KEY WORDS: Danube River, Extreme Hydrological Events, Flood Frequency Analysis, Peaks Over Threshold (POT) Method, Daily Runoff, Return Period.

Veronika Bačová-Mitková, Milan Onderka: ANALÝZA EXTRÉMNYCH HYDROLOGICKÝCH SITUÁCIÍ NA DUNAJI VYUŽITÍM METÓDY POT. J. Hydrol. Hydromech., 58, 2010, 2; 41 lit., 7 obr., 5 tab.

Príspevok sa zaoberá analýzou extrémnych hydrologických udalostí na Dunaji metódou Peak Over Threshold (POT). Metóda POT sa používa ako alternatíva určovania $N$-ročných prietokov $\mathrm{k}$ metóde ročných maxím pri analýzach extrémnych hydrologických udalostí. Pre výskyt vrcholových prietokov sa zvyčajne predpokladá Poissonova distribúcia.

Základnými vstupnými údajmi pre štatistickú analýzu sú 60-ročné časové rady priemerných denných prietokov a 60-ročné rady maximálnych ročných prietokov v nami zvolených staniciach: Achleiten, Kienstock, Viedeň, Bratislava a Nagymaros - za obdobie 1931-1990. Extrémne hydrologické udalosti na Dunaji boli analyzované metódou POT, ktorá zahŕňa všetky maximálne denné prietoky povodní za dané obdobie, presahujúce zvolenú prahovú hodnotu. Na zostavenie teoretickej čiary prekročenia boli vybrané dve teoretické rozdelenia pravdepodobnosti: logaritmicko-normálne rozdelenie (LN) a Pearsonovo rozdelenie III. typu (LP III). Druhým ciel'om príspevku bolo analyzovat' vplyv zmeny dížky časového radu na odhad $N$-ročných prietokov. V práci boli 60-ročné časové rady údajov skrátené na 40, 20 a 10-ročné rady. V závere sme porovnali a zhodnotili získané výsledky štatistických odhadov $N$-ročných prietokov vo zvolených staniciach. Z výsledkov analýzy vyplýva, že metóda POT dáva pomerne dobré odhady $N$-ročných prietokov aj pre krátke časové rady údajov.

KLÚČOVÉ SLOVÁ: tok Dunaja, extrémne hydrologické udalosti, frekvencia výskytu povodní, metóda POT, denný prietok, doba opakovania prietokov.

\section{Introduction}

The annual maximum series approach is the most frequent method used in probabilistic hydrology.
However, this approach considers only one value per year, which may result in loss of information. For example, some peaks within a year may be greater than the maximum discharge in other years 
hence they can be ignored (Kite, 1997; Chow et al., 1988). In principle, annual discharge maxima contain critical information on the peak flow, however their use is limited by two factors: 1 . the length of the series of annual maxima can be very short, 2 . the annual maxima time-series may be interrupted and thus they may not allow us to infer the antecedent conditions in the basin preceding a given peak. The first limiting factor produces uncertainties in interpreting statistical analyses, while the latter constrain implies that statistical models built on a phenomenological basis must rely on ancillary data in order to validate the underling hypotheses on the antecedent state of soil moisture (Claps and Laio, 2003).

This situation is avoided in the Peaks Over Threshold method (POT). Data series of the POT method considers all values exceeding a certain predefined threshold (Bayliss, 1999; Rao and $\mathrm{Ha}$ med, 2000). The POT method has been proposed as an alternative analytical tool to the method of annual discharge maxima for analysis of extreme hydrological events. This method was discussed in a number of papers (Langbein, 1949; Todorovic, 1970; Cunnane, 1973; Rosbjerg, 1977; Madsen at al. 1997 and Lang at al. 1999). In practice, however, it seems to be meaningful to consider not only the annual discharge maxima but also flood events that exceed safety limits. The idea is to derive the distribution and magnitude of annual floods from assumed distributions of the annual occurrence of events and the magnitudes of the POT. Shane and Lynn (1964) assumed that the Poisson distribution is valid for the occurrence of flood peaks, and flood magnitudes exhibit an exponential distribution. Zelenhasic (1970) investigated the distribution of annual maximum floods assuming the Poisson distribution for annual event occurrence and an exponential distribution for their magnitudes.

Önöz and Bayazit (2001) showed that for flood estimation, negative binomical (or binomical) models in combination with the exponential distribution of peak heights are almost identical in performance as the Poisson model. This result is in agreement with the findings of Kirby (1969) and Cunnane (1979), and makes it unnecessary to prefer the binomical or negative binomical models even when the Poisson process hypothesis is rejected by statistical tests. It is easier to use the Poisson model because it leads to much simpler expressions for the $\mathrm{N}$-year flood and its sampling variance.

In the 1980s and early 1990s the statistical method was generalized in different ways, including time-dependent parameters (North, 1980); correlated peak values (Rosbjerg, 1985), risk estimation (Konecny and Nachtnebel, 1985; Rasmussen and Rosbjerg, 1989), Bayesian approaches (Roussele and Hindie, 1976; Rasmussen and Rosbjerg, 1991 a)), a fixed number of peaks (Buishand, 1989), seasonality (Rasmussen and Rosbjerg, 1991b), and other alternatives to the exponential distribution of threshold exceedances such as Weibull (Ekanayake and Cruise, 1993), Lognormal (Rosbjerg, 1987 b); Rosbjerg et al., 1991), and the generalised Pareto (Davison and Smith, 1990; Wang, 1991; Rosbjerg et al., 1992). An extensive analysis of the methods for calculation of $N$-year discharges is given in the paper of Szolgay et al. 2003; Kohnová and Szolgay, 2000. Bača and Mitková, 2007 reported changes in the occurrence frequency of extreme hydrological events in a small agricultural basin using the POT method. The pros and cons of using either the POT method or series of annual discharge maxima for a statistical estimation of design values for the Danube-Bratislava station was investigated by Mitková et al. (2003).

Recently Lang at al. (1999) discussed the issue of threshold selection, models suitable for the occurrence processes of the peaks and for the distribution of their magnitudes, and the correspondence between the POT and annual maximum flood distributions. They concluded that the main difficulties of the POT approach concern the selection of the threshold level and of the occurrence process. Several applications of the POT method for estimates of design discharge have been shown in worldwide; however in Slovakia, this method has been rarely used. For example in the UK, the POT flood database of the Summary statistics and seasonality was carried out for POT method. This report describes the growth of the POT database, the data extraction procedures adopted, and it considers briefly the seasonality of flooding. The database now holds over 77000 peaks for 870 gauging stations throughout the UK with an average record length of nearly 20 years (Baylis and Jones, 1993).

The paper consists of two parts. The first part deals with the estimation of $N$-year discharges from the 1931-1990 period. The second part concerns the estimation of $\mathrm{N}$-year discharges from shorter data series. The purpose of this paper is to present alternative approaches for analysis of extreme hydrological events. Discharges with different return periods were estimated by the POT method and were finally compared with selected theoretical distributions of year discharge maxima. The POT 
method can give representative values of extreme flows from shorter time series and can be used to assess $\mathrm{N}$-year discharges.

\section{The POT method}

The basic idea is to extract from the daily discharges sequences a sample of peaks containing more than one flood peak per year, in order to increase the available information with respect to the annual maximum analysis.

The POT series includes all maximum discharges over the threshold. The number of the peaks $v$ in statistical series must be higher than $N$, where $N$ is the number of years on record.

The first threshold can be chosen near the longterm mean discharge. This value is rather low; POT series can have high diffusion and can include some insignificant maxims. Therefore, a threshold value is usually chosen so that POT data series includes in average 4 maximum values per year. In order to provide independence of the POT data the following criterions were used (Bayliss, 1999):

- Time period between two consequent peaks must be at least three times longer than the time of increasing of the first wave.

- Minimum discharge between two peaks must be less than $2 / 3$ of the peak height recoded during the first wave.

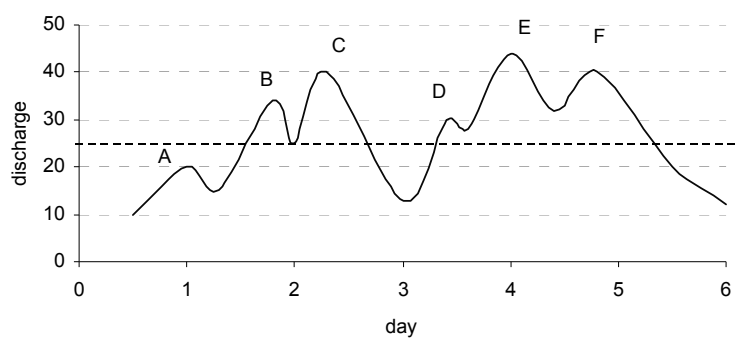

Fig. 1. Methodology of the $Q_{\text {POT }}$ selection. (Peaks E, C are included to POT data series).

Obr. 1. Aplikácia výberu údajov do súboru $Q_{\text {РОт }}$ (Vrcholy E, C sú zahrnuté do POT radu).

Application of the POT method for peak selection is presented in Fig. 1. The maximum discharge was obtained during the fourth day, therefore the peak E can be automatically included into the POT series. Increasing time of the wave E is about 15 hours. The peak D occurres less than 15 hours before peak E. Wave D is dependent, hence we cannot include this peak into the POT data series (the same situation is for peak wave F). The peak $\mathrm{C}$ is time independent from $\mathrm{E}$, and minimum discharge between $\mathrm{E}$ and $\mathrm{C}$ is less than $2 / 3$ of the $\mathrm{E}$, therefore the peak $\mathrm{C}$ can be included into the POT series. The peak of the wave A is less than the threshold and hence it cannot be included into the POT data series.

The POT method is characterised by two main variables:

- number of peaks in each year $v$;

- flow exceedances over threshold $Z_{v}=x-x_{B}$.

The occurrence of discharge maxima is a random process defined as:

$$
\chi(t)=\sup _{v \geq 1} Z_{v} ; Z_{v}=x-x_{B},
$$

where: $\chi(t)$ - occurrence of the discharge in time, $Z_{v}$ - exceedance of the discharge, $x_{B}$ - threshold value (discharge), $x$ - value of the current discharge (maxima discharge).

The distribution function of annual maxima is

$$
F(x)=P\{\chi(t) \leq x\} \text {. }
$$

\section{Number of peaks}

The number of peaks from the interval $(0, t)-$ one year in this analysis, is a random variable $\eta_{t}$ that can take values $0,1,2, \ldots$ with probabilities $p_{v}(t)=P\left\{\eta_{t}=v\right\}$.

The occurrence of peaks in this time interval is described as a Markov process with the intensity function

$$
\lambda(t, v)=\lim _{\Delta t \rightarrow 0} \frac{P\{\eta(t+\Delta t)-\eta(t)\}}{\Delta t},
$$

where $\lambda(t, v)$ - occurrence of peaks in time interval, $\eta$ - number of the peak, $t$ - time, $\Delta t$ - time difference of the occurrence of the number of peaks.

The probability of occurrence of peak exceedances is

$$
\begin{aligned}
& p^{\prime}{ }_{v}(t)=\lambda(t, v-1) p_{v-1}(t)-\lambda(t, v) p_{v}(t) . \\
& p^{\prime}{ }_{0}(t)=-\lambda(t, 0) p_{0}(t) .
\end{aligned}
$$

The solution to this equation (Eq. (4)) represents the probability law of occurrence of peaks and depends on the form of intensity function $\lambda$ (Vukmirovič, 1990). 


$$
\begin{gathered}
\lambda(t) \text { Poisson } \\
\lambda(t, v)=\lambda(t)(1-v / a) \text { Bernoulli (binomical) } \\
\lambda(t)(1+v / b) \text { Negative binomical }
\end{gathered}
$$

\section{Peaks over threshold}

Distribution function for peak exceedances flow is defined as:

$$
H(z)=P\{Z \leq z\} \text {. }
$$

Distribution can be generalized as three-parameter gamma distribution with density function:

$$
h(z)=\frac{a \Gamma^{k} \frac{k+1}{a}}{\mu \Gamma^{k+1}\left(\frac{k}{a}\right)}\left(\frac{z}{\mu}\right)^{k-1} \exp \left\{\left[\frac{\Gamma\left(\frac{k+1}{a}\right)}{\Gamma\left(\frac{k}{a}\right)}\right]^{a}\left(\frac{z}{\mu}\right)^{a}\right\}
$$

Distributions like two-parameter gamma, Weibull's, Erlang's or exponential are special cases of this general distribution. For estimation is recommended one-parameter distribution (exponential, Rayleigh's) or two-parameters distribution (Weibull or gamma).

Exponential $H(z)=1-\exp (-z / \mu)$, Weibull $\quad H(z)=1-\exp (z / \beta)^{\alpha}$,

where: $z$ - variables (magnitude of exceedance discharge over threshold), $\mu, \beta, \alpha$-distribution parameters.

\section{Annual maximum}

Distribution of annual maximum is obtained by combining the distributions of the number of peaks and distributions of peak exceedances over threshold value (Todorovič, 1970):

$F(x)=p_{0}+\sum_{v=1}^{\infty}[H(x)]^{v} p_{v}(t)$.

If the number of peaks follows the Poisson distributions then $F(x)$ has the form

$$
F(x)=\exp \{-\Lambda[1+H(x)]\} \text {. }
$$

\section{Return period}

Return period is defined by well-known equation

$$
R(x)=\frac{1}{1-F(x)} .
$$

\section{Study area}

The Danube is the second greatest river in Europe. The length of the Danube River is proximately $2830 \mathrm{~km}$ and drains a basin covering $817000 \mathrm{~km}^{2}$. Originating in the Black Forest in Germany at the confluence of the Brigach and the Breg streams, the Danube flows over some $2850 \mathrm{~km}$ before emptying into the Black Sea via the Danube Delta in Romania. The Slovak part of the Danube River is situated from $\mathrm{rkm} 1708.2$ (river $\mathrm{km}$ ) to $\mathrm{rkm} \mathrm{1880.2}$. About $7.5 \mathrm{~km}$ of the river creates a natural border to Austria, $22.5 \mathrm{~km}$ is in Slovakia and the rest of 142 $\mathrm{km}$ is the state border to Hungary (Fig. 2). Between the Vienna basin and the Danube lowland, the Danube flows in concentrated channel with relatively high bed slope. After leaving the Small

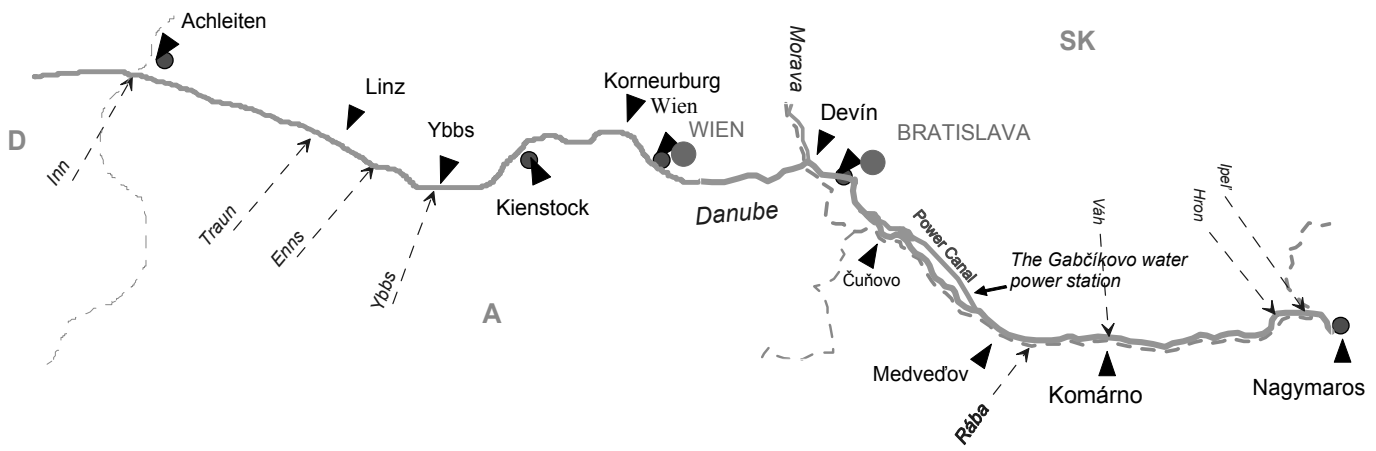

Fig. 2. Scheme of the selected profiles along the Danube River. (Circle points - selected stations.) Obr. 2. Schéma vybraného úseku povodia rieky Dunaj. (Vybrané stanice - kruhový bod.) 
3a)

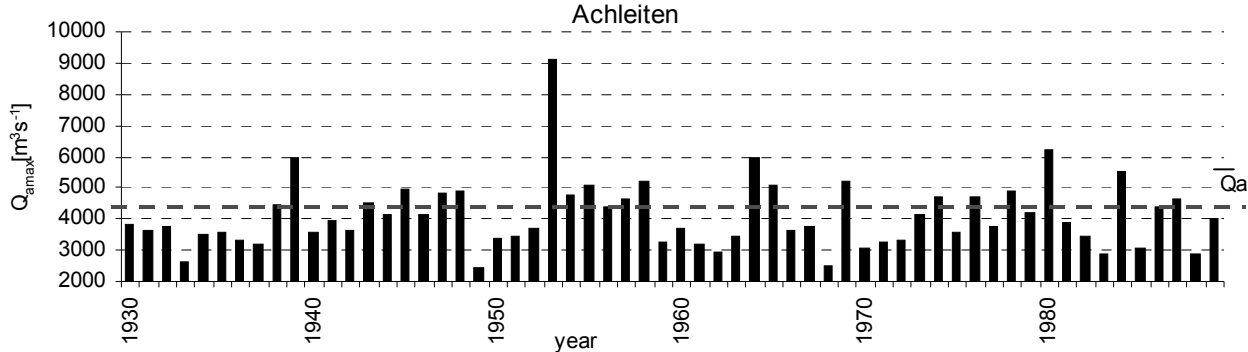

3b)

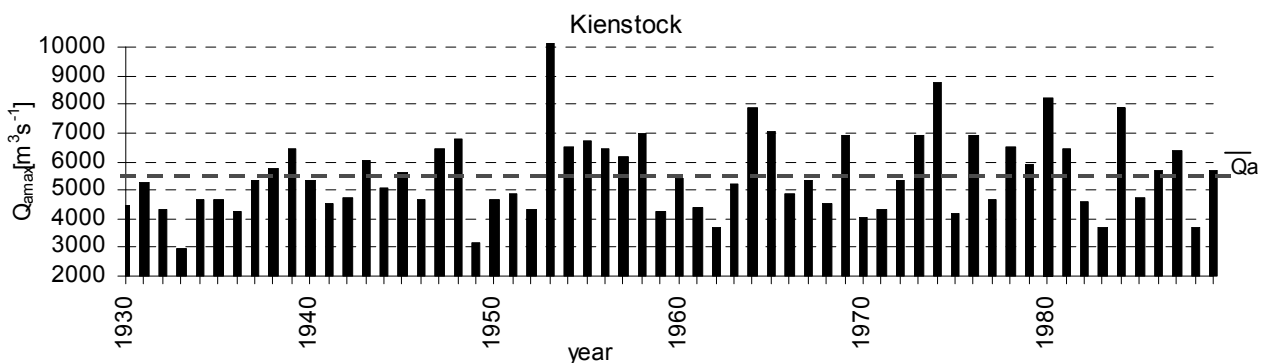

$3 c)$

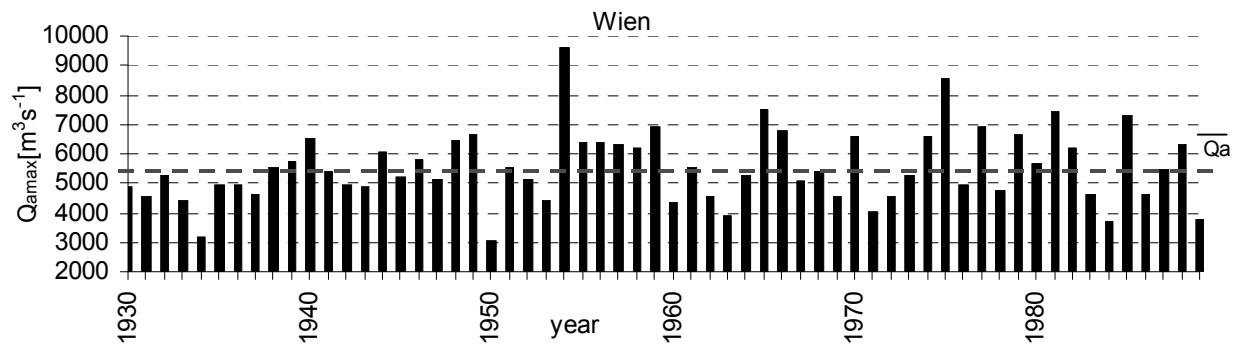

$3 \mathrm{~d})$

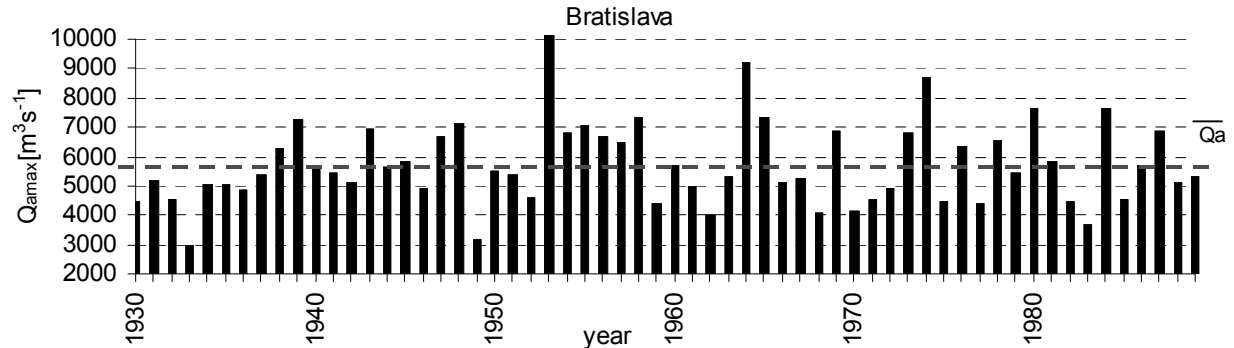

3e)

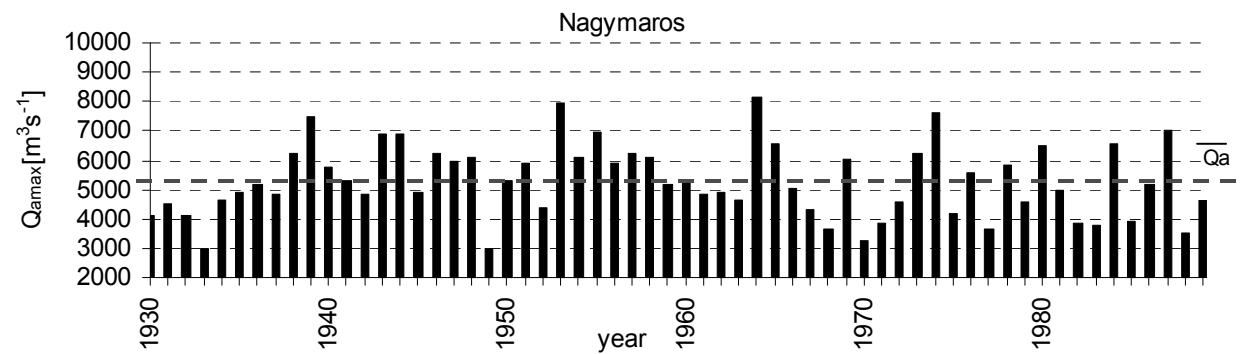

Fig. 3 a)-e) The annual maximum discharges during period 1931-1990 ( $\overline{Q a}-$ long term mean annual maximum discharge). Obr. 3 a)-e) Maximálne ročné prietoky počas rokov $1931-1990$ ( $\overline{Q a}$ - dlhodobý priemerný ročný maximálny prietok). 
Carpathians it keeps the slope and flows over its alluvial cone through a complicated network of branches and meanders downstream to the town of Medvedov. The different physical features of the river basin affect the amount of water runoff in its three sections. In the upper Danube, the runoff corresponds to that of the Alpine tributaries, where the maximum occurs in June when melting of snow and ice in the Alps is the most intensive. Runoff drops to its lowest point during the winter months.

In the middle basin the phases last up to four months, with two runoff peaks in June and April. The April peak is local. It is caused by the addition of waters from the melting snow in the plains and from the early spring rains of the lowland and the low mountains of the area. Rainfall is important; the period of low water begins in October and reflects the dry spells of summer and autumn that are characteristic of the low plains.

\section{Water discharge data and method}

River regime conditions of the Danube River are subject to temporal changes. These changes result from natural processes (erosion, sedimentation, vegetation cover) or anthropogenic activities (training works, construction of hydropower stations). Due to water flow changes on the Danube River it is impossible to determine the full range of hydrological characteristics (for example $Q_{100}$ ) only from the range of historical discharges at given gauging stations. Differences between peak discharges and daily means of the Danube River at Bratislava are changed about $166 \mathrm{~m}^{3} \mathrm{~s}^{-1}$ (3.5\%) during the period 1917-2002. This difference is not significant for a large river such as the Danube River. Therefore, the POT method has been applied to daily discharge time series at selected gauging stations: Achleiten, Kienstock, Wien, Bratislava and Nagymaros.

These gauging stations were chosen based on the availability of long-term discharge records. The record covers a period of 60 years (1931-1990). The annual maxima discharges are shown in Figs. 3 a)-e).

The work consists of two parts. The first part is aimed at the POT method application on all selected data period. The second part concerns the estimation of $\mathrm{N}$-year discharges from shorter data series and the impact of the shortening data time series on the estimation of the design discharges. The daily discharges series of the period of 60 years were divided into three periods:
1. period of 40 years (1931-1971) and (1950$-1990)$

2. period of 20 years (1931-1951) and (1970$-1990)$;

3. period of 10 years (1931-1941) and (1980-1990).

Period selection and period dividing of the data series is a subjective process. Therefore, with regard to later regulations of the Danube channel bank the 40, 20 and 10 year time data series were chosen in early of the 60-year period and second analysed time data series were chosen from the end of the 60-year period.

The threshold value at level limit on 0.85 percentile from mean daily discharges was chosen. The next, three filters were used to provide independence of the POT data. Theoretical Weibull distribution was applied for estimation $N$-year discharges over threshold and number of peaks has Poisson distribution.

A probability of the empirical exceedance curves of the maximum annual discharges in this methodology was determined by Cunnane (1988) relationship.

$P=\frac{m-0.4}{n+0.2}$

where $n$ is number of the years and $m$ - serial number of the sort values.

Basic hydrological parameters for assessment of the multi annual runoff are: $\overline{Q a}$ long term mean annual maximum discharge, $C v$ - coefficient of variation, $C s-$ coefficient of asymmetry (Tab. 1). Log-normal distribution and Log-Pearson type III distribution are one of the most frequently used distributions in hydrology. Log-normal distribution is statistical distribution for which the log of the random variable is distributed normally. The LogPearson type III distribution (LP3) is a very important model in statistical hydrology. It is a flexible three-parameter family capable of taking many different shapes and has been widely used in many countries for modelling original (untransformed) annual flood series.

Kolmogorov-Smirnov test for the evaluation of the theoretical distribution functions was used. In this type of test, the values of a tested sequence are not divided into classes - hence the test is particularly suitable for continuous distributions where the empirical distribution function $F_{n}(x)$ is tested for consistency with an anticipated theoretical distribu- 
$\mathrm{T}$ a b l e 1. Main statistical characteristics of the annual maximum discharges.

$\mathrm{T}$ a b u l'k a 1 . Hlavné štatistické charakteristiky ročných maximálnych prietokov.

\begin{tabular}{|c|c|c|c|c|c|c|}
\hline Period & & $\overline{\mathrm{ACH}}$ & KIE & WIE & $\mathrm{BA}$ & NGM \\
\hline \multirow{3}{*}{ 1931-1990 } & $\bar{Q} \mathrm{a}\left[\mathrm{m}^{3} \mathrm{~s}^{-1}\right]$ & 4121.21 & 5597.87 & 5535.77 & 5718.28 & 5365.74 \\
\hline & $\mathrm{Cs}$ & 1.71 & 0.92 & 0.68 & 0.85 & 0.63 \\
\hline & $\mathrm{Cv}$ & 0.27 & 0.27 & 0.22 & 0.25 & 0.25 \\
\hline \multirow{3}{*}{ 1931-1970 } & $\bar{Q} \mathrm{a}\left[\mathrm{m}^{3} \mathrm{~s}^{-1}\right]$ & 4116.05 & 5416.95 & 5499.58 & 5745.18 & 5434.40 \\
\hline & Cs & 1.93 & 1.09 & 0.81 & 0.91 & 0.08 \\
\hline & $\mathrm{Cv}$ & 0.29 & 0.25 & 0.22 & 0.25 & 0.23 \\
\hline \multirow{3}{*}{ 1931-1960 } & $\bar{Q} \mathrm{a}\left[\mathrm{m}^{3} \mathrm{~s}^{-1}\right]$ & 3923.50 & 5038.90 & 5220.85 & 5432.60 & 5302.50 \\
\hline & Cs & 0.51 & -0.27 & -0.80 & -0.42 & -0.26 \\
\hline & $\mathrm{Cv}$ & 0.22 & 0.20 & 0.18 & 0.21 & 0.22 \\
\hline \multirow{3}{*}{ 1931-1940 } & $\bar{Q} \mathrm{a}\left[\mathrm{m}^{3} \mathrm{~s}^{-1}\right]$ & 3756.00 & 4906.60 & 4978.40 & 5226.10 & 5075.00 \\
\hline & Cs & 1.76 & -0.51 & -0.39 & -0.18 & 0.39 \\
\hline & $\mathrm{Cv}$ & 0.24 & 0.19 & 0.18 & 0.21 & 0.24 \\
\hline \multirow{3}{*}{ 1950-1990 } & $\bar{Q} \mathrm{a}\left[\mathrm{m}^{3} \mathrm{~s}^{-1}\right]$ & 4200.92 & 5906.58 & 5733.80 & 5895.80 & 5428.00 \\
\hline & Cs & 1.86 & 0.76 & 0.72 & 0.95 & 0.80 \\
\hline & $\mathrm{Cv}$ & 0.29 & 0.28 & 0.23 & 0.26 & 0.36 \\
\hline \multirow{3}{*}{ 1970-1970 } & $\bar{Q} \mathrm{a}\left[\mathrm{m}^{3} \mathrm{~s}^{-1}\right]$ & 4086.67 & 6018.15 & 5641.10 & 5649.38 & 5289.70 \\
\hline & Cs & 0.62 & 0.54 & 0.43 & 0.71 & 1.20 \\
\hline & $\mathrm{Cv}$ & 0.22 & 0.28 & 0.24 & 0.24 & 0.30 \\
\hline \multirow{3}{*}{ 1980-1960 } & $\bar{Q} \mathrm{a}\left[\mathrm{m}^{3} \mathrm{~s}^{-1}\right]$ & 4102.20 & 5845.70 & 5477.50 & 5657.64 & 5006.30 \\
\hline & Cs & 0.77 & 0.87 & 0.14 & 0.41 & 0.49 \\
\hline & $\mathrm{Cv}$ & 0.27 & 0.32 & 0.24 & 0.23 & 0.26 \\
\hline
\end{tabular}

tion function $F(x)$. Due to results of the Kolmogorov-Smirnov test we cannot reject hypothesis that daily maxima discharges comes from these distributions with $95 \%$ confidence. Therefore, theoretical distribution probability functions were used for parameters estimating of the theoretical probability curve of the maximum annual discharges: Lognormal distribution (LN) and Log-Pearson distribution III type (LP3).

In this work two approaches of the estimating $N$ year discharges were compared. The POT method (Vukmirovič, Petrovič, 1995) has been compared with selected theoretical distribution functions of the annual maximum discharges.

\section{Results}

The Peak Over Threshold (POT) method has been used to analyse the extreme hydrological events on the Danube River. The POT method was applied to daily discharge time series over the period of 60 years (1931-1990). Our approach is based on application of the Weibull distribution for estimating of the $N$-year discharges over the POT threshold values (Figs. 4 a)-e)). Number of peaks has Poisson distribution and average numbers of peaks per year for the whole period are presented in Tab. 2 with the maximum value (203 peaks) for gauging station Kienstock. Distribution of the annual maxima discharges is obtained by combination of two mentioned distributions: 1 . distribution of peak over threshold values and 2. the number of peaks distribution. Computed values of the $\mathrm{N}$-year discharges over the period 1931-1990 are shown in Fig. 5. As noted above, the Log-normal distribution and LogPearson III type distribution were used for parameters estimation of the theoretical exceedance curves. The POT method gives higher $Q 100$ and $Q 1000$ discharge values than other applied distributions for gauging stations Bratislava and Wien during the period 1931-1990 (Fig. 5).

Beňacká (1976), Zatkalik (1965), and Svoboda (2000) present higher values of the discharges with the return period 100 and 1000 years than the values obtained by our statistical analysis. It may be resulted from our data period selection and the fact that some of the highest maximum discharges that were recorded on the Danube River were not taken into account for our analysis (historical floods occurred in the years 1501 and 1899). 


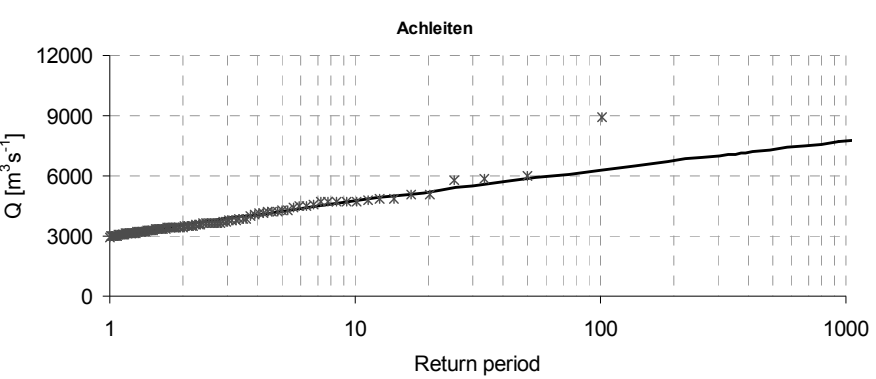

4 a)

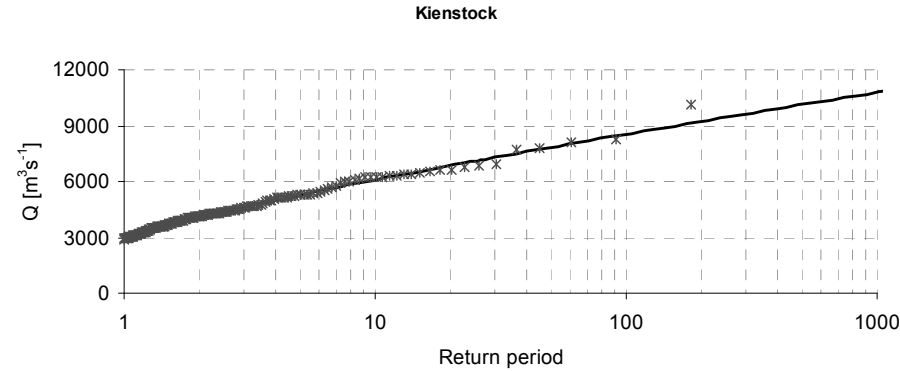

4 b)

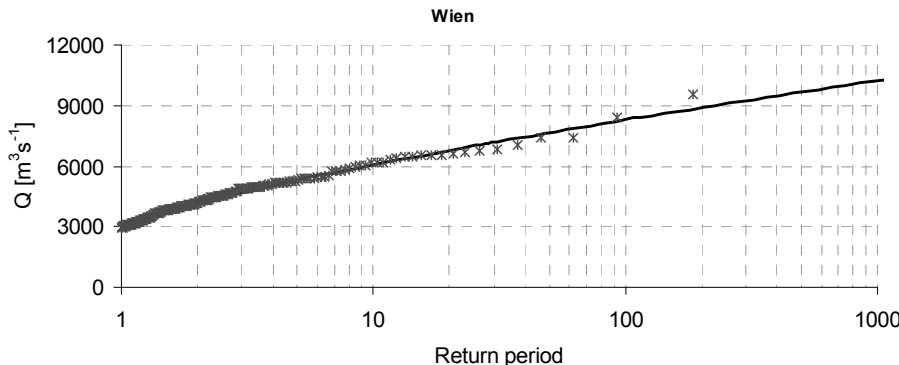

$4 \mathrm{c})$

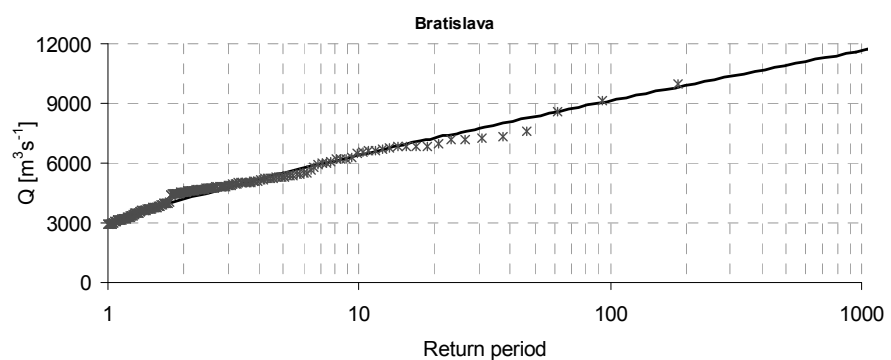

$4 d)$

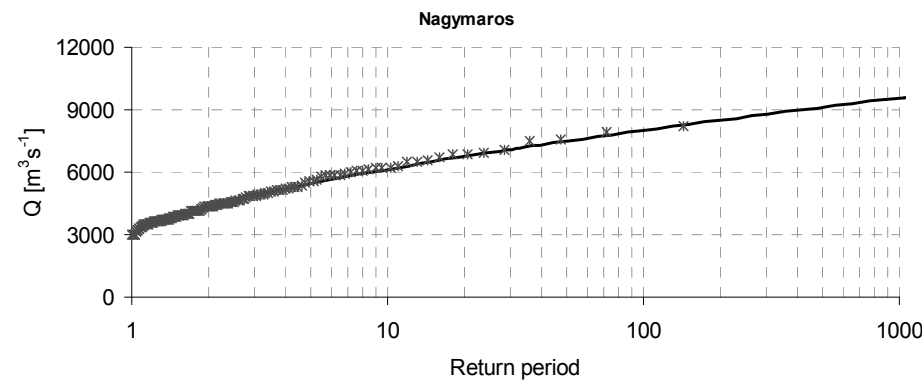

4 e)

Fig. 4. Line of the return period of the discharges over threshold for the Danube during the period 1931-1990 (Weibull). Obr. 4. Čiara doby opakovania prietokov nad prahovou hodnotou na Dunaji počas obdobia r. 1931-1990 (Weibull). 
T a b l e 2. The Poisson distribution of the number of the peaks (1931-1990).

T a b u l'k a 2. Poissonova distribúcia počtu vrcholov (1931-1990).

\begin{tabular}{cccccc}
\hline & Achleiten & Kienstock & Wien & Bratislava & Nagymaros \\
\hline Peak/year & 3.2 & 3.4 & 3.3 & 3.1 & 2.2 \\
Peak No. & 190 & 203 & 200 & 186 & 133 \\
\hline
\end{tabular}
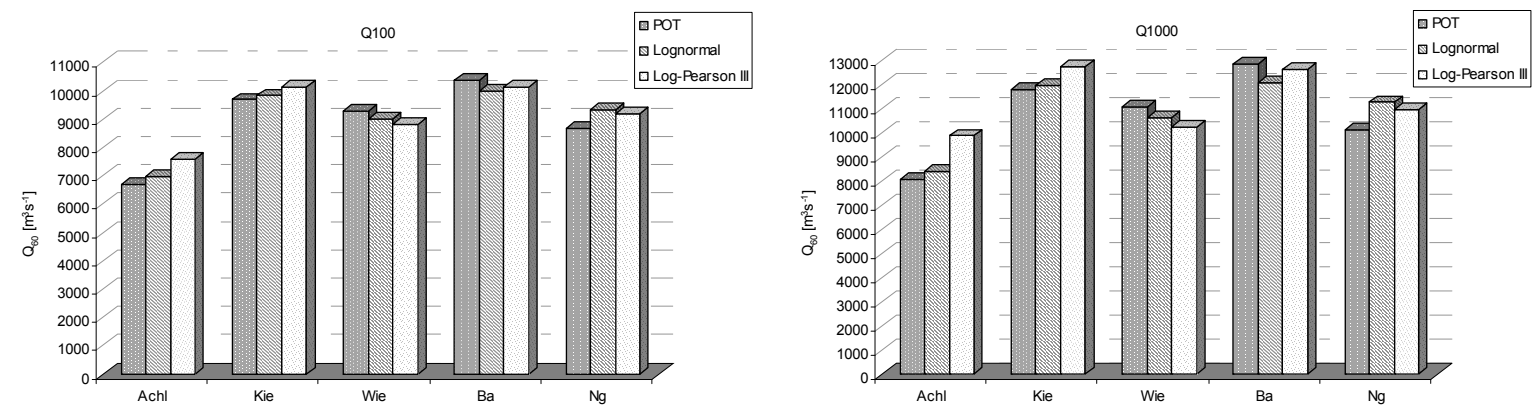

Fig. 5. Discharges of the Danube River with return period 100 and 1000 years according to POT method, Log-normal distribution and Log-Pearson III distribution (60-year period).

Obr. 5. Prietoky Dunaja s dobou opakovania 100 a 1000 rokov podl’a POT metódy, logaritmicko-normálnej distribúcie a Pearsonovho rozdelenia III (60-ročný rad).

T a b 1 e 3. The Poisson distribution of the number of the peaks for periods 1931-1970, 1931-1950, 1931-1941 and periods 19501990, 1970-1990 and 1980-1990.

T a b u l' k a 3. Poissonova distribúcia počtu vrcholov pre obdobie 1931-1970, 1931-1951, 1931-1941 a obdobie1950-1970, $1970-1990$ a $1980-1990$.

\begin{tabular}{cccccc}
\hline 1931-1970 & Achleiten & Kienstock & Wien & Bratislava & Nagymaros \\
\hline Peak/year & 3.1 & 3 & 3.3 & 2.8 & 2.1 \\
Peak No. & 123 & 120 & 130 & 112 & 84 \\
\hline $1931-1950$ & Achleiten & Kienstock & Wien & Bratislava & Nagymaros \\
\hline Peak/year & 3.2 & 3.2 & 3.1 & 2.7 & 1.9 \\
Peak No. & 63 & 64 & 62 & 54 & 38 \\
\hline $1931-1941$ & Achleiten & Kienstock & Wien & Bratislava & Nagymaros \\
\hline Peak/year & 3 & 3.2 & 3.2 & 2.9 & 2.1 \\
Peak No. & 30 & 30 & 32 & 29 & 21 \\
\hline $1950-1990$ & Achleiten & Kienstock & Wien & Bratislava & Nagymaros \\
\hline Peak/year & 3.33 & 3.475 & 3.37 & 3.35 & 2.37 \\
Peak No. & 130 & 19 & 135 & 134 & 95 \\
\hline $1970-1990$ & Achleiten & Kienstock & Wien & Bratislava & Nagymaros \\
\hline Peak/year & 3.25 & 3.5 & 3.45 & 3.7 & 2.55 \\
Peak No. & 65 & 70 & 69 & 74 & 51 \\
\hline $1980-1990$ & Achleiten & Kienstock & Wien & Bratislava & Nagymaros \\
\hline Peak/year & 3.9 & 3.7 & 3.6 & 4.1 & 3 \\
Peak No. & 39 & 37 & 36 & 41 & 30 \\
\hline
\end{tabular}

For example recommended discharge values with the return period of 100-years, and 1000-years, for Bratislava are about $11000 \mathrm{~m}^{3} \mathrm{~s}^{-1}$ and $13500 \mathrm{~m}^{3}$ $\mathrm{s}^{-1}$ respectively, and the values estimated by the POT method were $10400 \mathrm{~m}^{3} \mathrm{~s}^{-1}$ and $12900 \mathrm{~m}^{3} \mathrm{~s}^{-1}$ respectively, for the period of 60 years (Tab. 4).

The same approach was used for the analysis of the following data time series, 1931-1940, 19311950, 1931-1970, 1950-1990, 1970-1990 and 1980-1990 (Tab. 3). As shown, the mean number of the peaks over the threshold for all gauging stations is about 3 peaks per/year.

The estimated values of the $N$-year discharges over the shorter periods 1931-1970, 1931-1950 and 1931-1940 are shown in Figs. 6 a)-e). This figure reveals that the statistical method selection and its application to data series collection have influence to results of the statistical analysis. The application of the POT method for the period of 20 years gives comparable or higher values of the 
$\mathrm{T}$ a b $1 \mathrm{e}$ 4. Comparison of the discharges with return period 100 and 1000 years for period 1931-1990.

T a b u l'k a. 4. Porovnanie 100- a 1000-ročných prietokov pre časový rad r. 1931-1990.

\begin{tabular}{|c|c|c|c|}
\hline$Q n\left[\mathrm{~m}^{3} \mathrm{~s}^{-1}\right]$ & \multicolumn{2}{|c|}{ 1931-1990 } & \\
\hline 100 & POT & $\mathrm{LN}$ & LP3 \\
\hline Achl & 6720 & 7000 & 7595 \\
\hline Kie & 9900 & 9845 & 10164 \\
\hline Wei & 9170 & 9008 & 8842 \\
\hline $\mathrm{Ba}$ & 10400 & 10018 & 10163 \\
\hline $\mathrm{Ng}$ & 9000 & 9328 & 9194 \\
\hline 1000 & POT & LN & LP3 \\
\hline Achl & 8120 & 8425 & 9904 \\
\hline Kie & 12150 & 11978 & 12755 \\
\hline Wei & 10970 & 10651 & 10278 \\
\hline $\mathrm{Ba}$ & 12900 & 12119 & 12645 \\
\hline $\mathrm{Ng}$ & 10850 & 11298 & 10989 \\
\hline
\end{tabular}
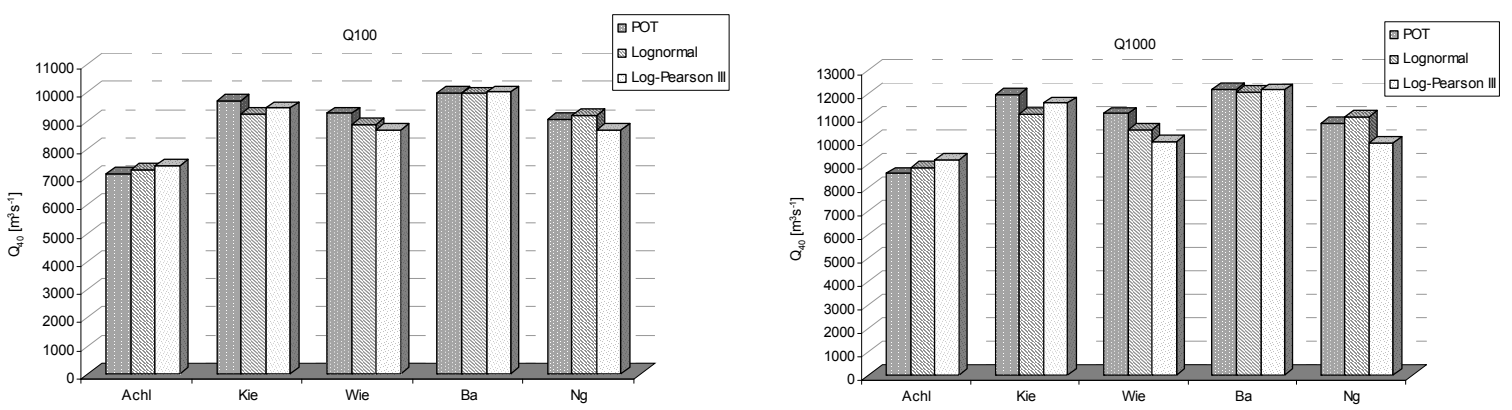

a)
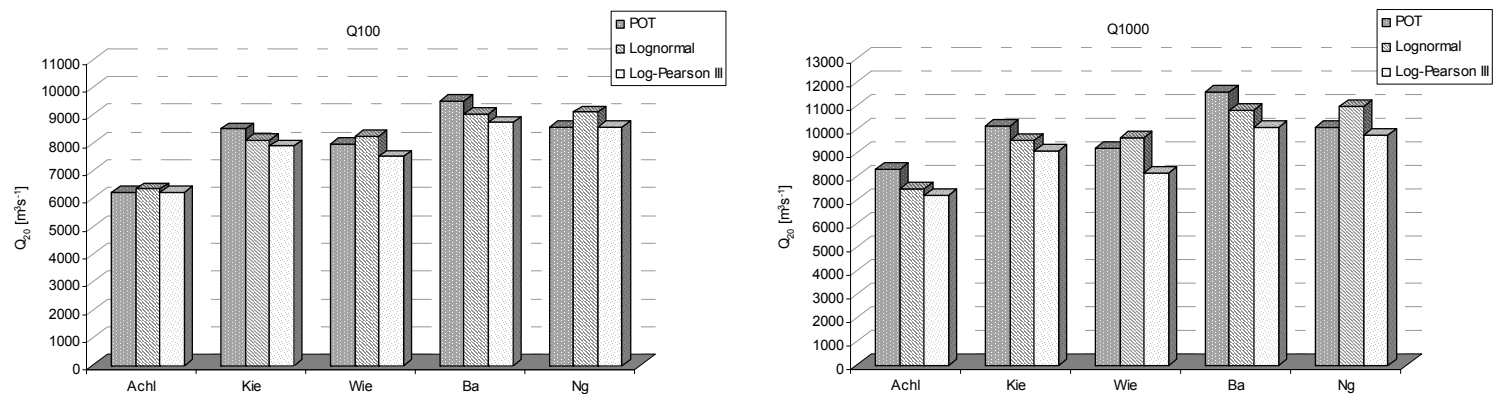

b)
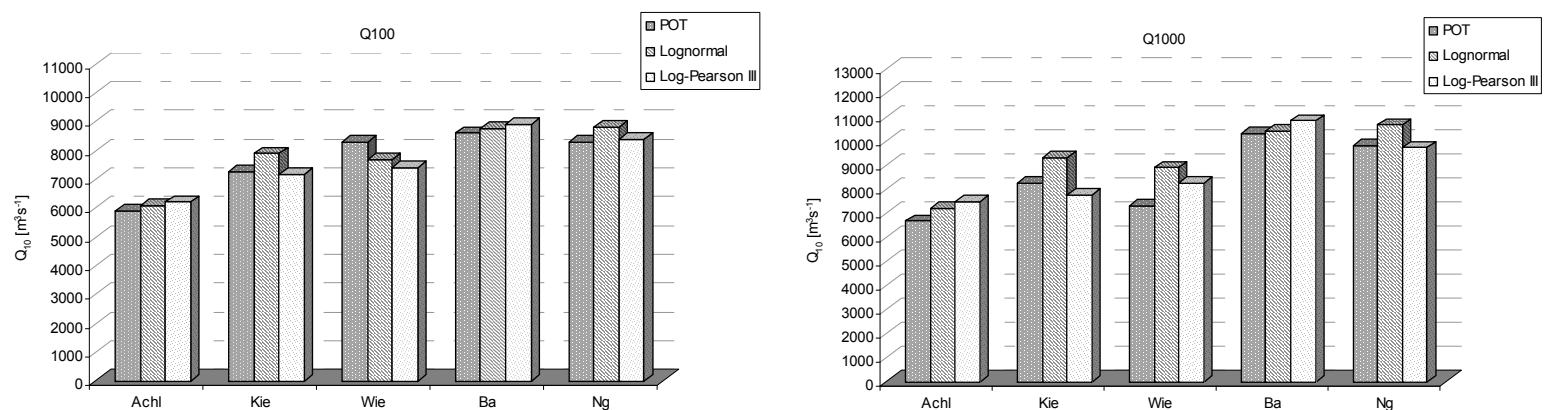

c)

Fig. 6. Discharges of the Danube River with return period 100 and 1000 years according to POT method, Log-normal distribution and Log-Pearson III distribution; a) 1931-1970, b) 1931-1960, c) 1931-1940.

Obr. 6. Prietoky Dunaja s dobou opakovania 100 a 1000 rokov podl'a POT metódy, logaritmicko-normálnej distribúcie a Pearsonovho rozdelenia III; a) 1931-1970, b) 1931-1960, c) 1931-1940. 

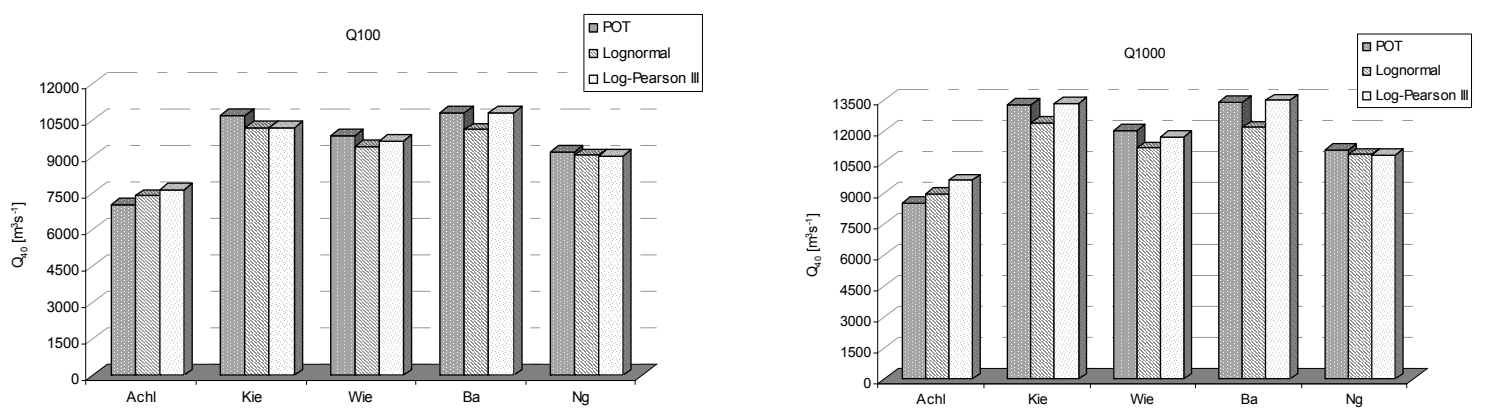

a)
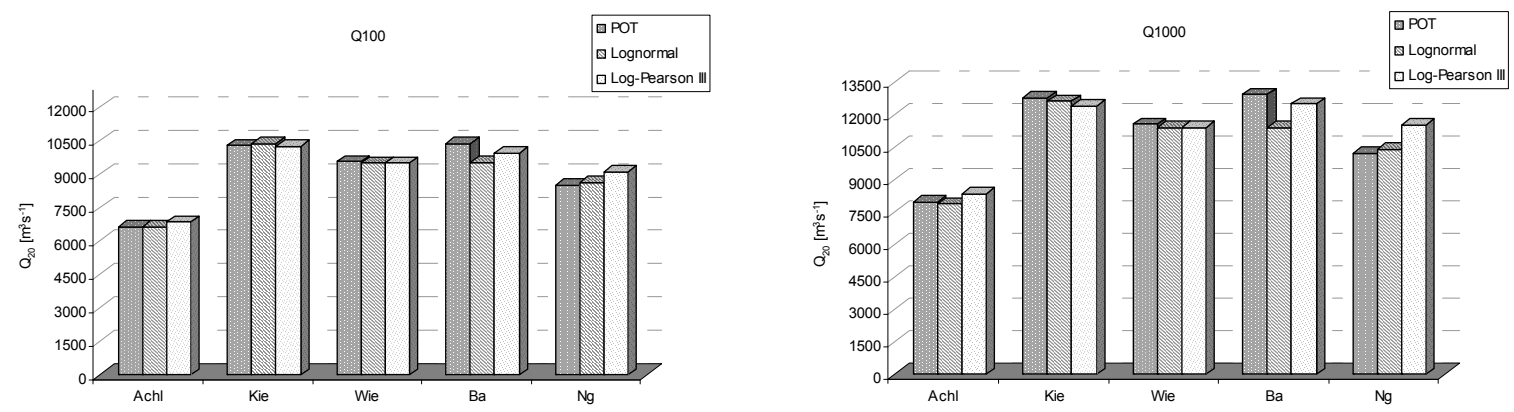

b)
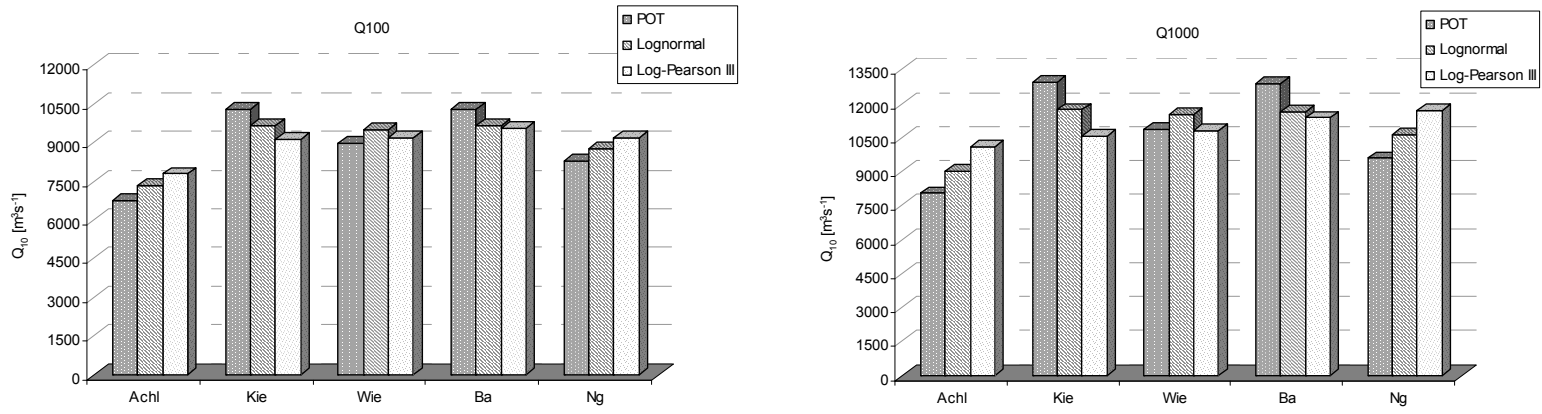

c)

Fig. 7. Discharges of the Danube River with return period 100 and 1000 years according to POT method, Log-normal distribution and Log-Pearson III distribution; a) 1950-1990, b) 1970-1990, c) 1980-1990).

Obr. 7. Prietoky Dunaja s dobou opakovania 100 a 1000 rokov podl'a POT metódy, logaritmicko-normálnej distribúcie a Pearsonovho rozdelenia III; a) 1950-1990, b) 1970-1990, c) 1980-1990).

$N$-year discharge estimations for stations Achleiten, Kienstock, Wien and Bratislava than the traditional analysis of annual discharge maxima. However, lower discharge values were obtained by the POT method in comparison with the Log-normal distribution for the Nagymaros station.

The highest values of the $N$-year discharges during the periods 1950-1990, 1970-1990 and 1980-1990 were obtained by the POT method for the most gauging stations (Figs 7 a) $-c)$ )). From a comparison of the results of the beginning and the end of our 60-year data period it can be concluded that the differences between the values of $N$-year discharges increased. For instance the difference for $Q_{100}$ at Kienstock is about $2279 \mathrm{~m}^{3} \mathrm{~s}^{-1}$ and for $Q_{1000}$ is about $3339 \mathrm{~m}^{3} \mathrm{~s}^{-1}$ (10-year period, Tab. 5).

The results show that the differences between the discharge estimations obtained by statistical methods was $Q_{100}=4.8 \%$ and $Q_{1000}=7 \%$ respectively during the period of 60 years. The maximum difference was obtained for $Q_{100}=6.9 \%$ and $Q_{1000}=9 \%$ respectively during the period of 10 years (1980$-1990)$. 
Analysis of extreme hydrological events on the Danube using the Peak Over Threshold method

$\mathrm{T}$ a b 1 e 5. Comparison of the discharges with return period 100 and 1000 years for different length of the data series. T a b u l' k a 5. Porovnanie odhadnutých 100- a 1000-ročných prietokov pre rôzne dížky časových radov pozorovaní.

\begin{tabular}{|c|c|c|c|c|c|c|c|c|c|}
\hline$\left[\mathrm{m}^{3} \mathrm{~s}^{-1}\right]$ & \multicolumn{3}{|c|}{$1931-1971$} & \multicolumn{3}{|c|}{$1931-1951$} & \multicolumn{3}{|c|}{ 1931-1941 } \\
\hline 100 & POT & $\mathrm{LN}$ & LP3 & POT & LN & LP3 & POT & $\mathrm{LN}$ & LP3 \\
\hline Achl & 7120 & 7271 & 7400 & 6220 & 6342 & 6208 & 5900 & 6085 & 6207 \\
\hline Kie & 9700 & 9253 & 9453 & 8500 & 8102 & 7890 & 7250 & 7890 & 7148 \\
\hline Wei & 9270 & 8882 & 8663 & 7970 & 8226 & 7515 & 8300 & 7668 & 7382 \\
\hline $\mathrm{Ba}$ & 10000 & 9976 & 10017 & 9500 & 9047 & 8737 & 8590 & 8741 & 8910 \\
\hline $\mathrm{Ng}$ & 9050 & 9202 & 8694 & 8572 & 9108 & 8553 & 8300 & 8813 & 8391 \\
\hline 1000 & POT & LN & LP3 & POT & LN & LP3 & POT & LN & LP3 \\
\hline Achl & 8620 & 8866 & 9201 & 8320 & 7480 & 7178 & 6670 & 7183 & 7467 \\
\hline Kie & 12000 & 11137 & 11614 & 10150 & 9533 & 9063 & 8250 & 9280 & 7738 \\
\hline Wei & 11170 & 10473 & 9984 & 9200 & 9608 & 8132 & 7300 & 8882 & 8264 \\
\hline $\mathrm{Ba}$ & 12200 & 12078 & 12174 & 11560 & 10779 & 10084 & 10300 & 10420 & 10825 \\
\hline $\mathrm{Ng}$ & 10760 & 11035 & 9912 & 10075 & 10973 & 9749 & 9800 & 10658 & 9711 \\
\hline$\left[\mathrm{m}^{3} \mathrm{~s}^{-1}\right]$ & \multicolumn{3}{|c|}{$1950-1990$} & \multicolumn{3}{|c|}{ 1970-1990 } & \multicolumn{3}{|c|}{$1980-1990$} \\
\hline 100 & POT & LN & LP3 & POT & $\mathrm{LN}$ & LP3 & POT & LN & LP3 \\
\hline Achl & 7020 & 7381 & 7646 & 6660 & 6659 & 6866 & 6760 & 7363 & 7790 \\
\hline Kie & 10700 & 10210 & 10188 & 10300 & 10367 & 10259 & 10300 & 9678 & 9154 \\
\hline Wei & 9850 & 9427 & 9651 & 9570 & 9509 & 9512 & 8988 & 9528 & 9212 \\
\hline $\mathrm{Ba}$ & 10800 & 10105 & 10813 & 10400 & 9526 & 9981 & 10300 & 9686 & 9578 \\
\hline $\mathrm{Ng}$ & 9200 & 9052 & 9031 & 8500 & 8638 & 9099 & 8300 & 8770 & 9212 \\
\hline 1000 & POT & LN & LP3 & POT & LN & LP3 & POT & LN & LP3 \\
\hline Achl & 8520 & 8981 & 9628 & 7960 & 7877 & 8328 & 8060 & 9018 & 10106 \\
\hline Kie & 13300 & 12418 & 13338 & 12800 & 12626 & 12422 & 1252 & 11737 & 10564 \\
\hline Wei & 12050 & 11190 & 11716 & 11570 & 11386 & 11390 & 10878 & 11521 & 10812 \\
\hline $\mathrm{Ba}$ & 13400 & 12180 & 13938 & 12940 & 11401 & 12499 & 12900 & 11630 & 11385 \\
\hline $\mathrm{Ng}$ & 11100 & 11649 & 12498 & 10200 & 10395 & 11520 & 9600 & 10650 & 11725 \\
\hline
\end{tabular}

\section{Conclusion and discussion}

The paper presents the results of our analysis of extreme hydrological events on the Danube River by the Peak Over Threshold method (POT). The first part of the paper presents the methodology of POT approach for the estimation of $N$-year discharges at 5 gauging stations in the period 1931-1990. We have described two methods for estimating $\mathrm{N}$-year discharges: the peak over threshold method and the annual maxima discharges method.

To apply the POT method is more difficult because a user himself has to choose a threshold. In this paper we have chosen the threshold to $85 \%$ quintile of all daily discharges. For the theoretical exceedance curves of annual maxima discharges were chosen the Log-normal and Log-Pearson III distributions. To evaluate the appropriateness of the theoretical distribution functions we used the Kolmogorov-Smirnov test. The POT and other distributions of the maximum discharge maxima (LN, LP3) were finally compared. The quality and stability of estimated $N$-year discharges is affected by many different properties of the studying data set.

Second part analyzed the impact of record length on the estimation of discharge with different return periods. The result of our analysis indicates that the
POT method can provide adequate or even comparable results to the $N$-year discharge estimates when used for multiple stations with short data coverage. In summary, the primary advantage of using the POT method is that it enables estimation of $N$-year discharge from shorter time-series, and that the set of analyzed values involves less significant flood events that reflect the hydrological conditions in a basin. Second, the seasonality may also affect the obtained estimates then is better the series split into more homogenous sets, e.g. seasons. Jarušková and Hanek (2006) compared POT method with blokmaxima method for estimating of high return period of discharges series and resulted that the blockmaxima method is much more sensitive to one large observation. Giesecke et al (2002) and Szolgay et al. (2003) concluded that the statistical manner of the data series and uncertainty of statistical estimation are in accordance with the internal structure of data series. They asked: "Is it necessary to use all observations or is it better to choose only some periods due to hydrological, climatic and water management requirements?"

Acknowledgements. This research was supported by the MVTS project "Flood regime of rivers in the Danube River basin", the Science Granting Agency under the contract No. VEGA 0096. 


\section{REFERENCES}

BAČA P., MITKOVÁ V., 2007: Analysis of seasonal extreme flows using Peaks Over Threshold method. J. Hydrol. Hydromech., Vol. 55, No. 1, p. 16-22.

BAYLISS A.C., JONES R.C., 1993: Peaks-over-threshold flood database: summary statistics and seasonality. Report No. 121, Institute of Hydrology, Wallingford, UK.

BAYLISS A. C., 1999: Deriving flood peak data. Flood estimation Handbook. Vol. 3, p. 273-283.

BEŇACKÁ O., 1976: Hydrologic Monograph of the Czechoslovak Danube Catchment. Part I Water Balance. (In Slovak.) Research reports S-R-531-VH-03-02. VÚVH, Bratislava.

BUISHAND T.A., 1989: The partial duration series with a fixed number of peaks. J. Hydrology, 109, 1-9.

CLAPS P., LIO F., 2003: Can continuous stream flow data support flood frequency analysis? An alternative to the partial duration series approach. Water Resour. Res., 39, 8, p. 1216.

CUNNANE C., 1973: A particular comparison of annual maxima and partial duration series methods of flood frequency prediction. Journal of Hydrology, 18, p. 257-271.

CUNNANE C., 1979: A note on Poisson assumption in partial duration series model. Water Resour. Res., 15, 2, p. 489 $-494$.

DAVISON A.C., SMITH R.L., 1990: Models for exceedances over high thresholds. J.R. Stat. Soc., 52, p. 393-442.

EKANAYAKE S.T., CRUISE J.F., 1992: Comparisons of Weibull and exponential based partial duration stochastic flood models. Stochastic Hydrol. Hydraul., 7, p. 283-297.

GIESECKE J., BARDOSSY A., MARKOVICH D., 2002: Extremwertstatistik. Endbericht. Bundesanstalt fuer Gewaessserkunde, Koblenz, 2002. 49 s.

CHOW V. T., MAIDMENT D. R., MAYS L.W., 1988: Applied hydrology. McGraw-Hill, New York, NY.

JARUŠKOVÁ D., HANEK M., 2006: Peaks over threshold method in comparison with block-maxima method for estimating high return levels of several Northern Moravia precipitation and discharges series. J. Hydrol. Hydromech., Vol. 54, No. 4, p. 309-319.

KIRBY W., 1969: On the random occurrence of major floods. Water Resour. Res., 5, 4, p. 778-789.

KITE G.W., 1977: Frequency and risk analysis in hydrology. Water Res. Publications, Fort Collins, CO.

KOHNOVÁ S., SZOLGAY J., 2000: Regional estimation of design flood discharges for river restoration in mountainous basins of northern Slovakia. In: Marsalek, et al. (eds.), Flood Issues in Contemporary Water Management, NATO Science Series, Vol. 71. Kluwer Academic Publishers, p. 41-47.

KONECNY F, NACHTNEBEL H.P., 1985: Extreme value processes and the evaluation of risk in flood analysis. Appl. Math. Modelling, 9, p. 11-15.

LANG M., OUARDA T.B M. J., BOBEE B., 1999: Towards operational quid lines for over threshold modelling. J. Hydrol., 225, p. 103-117.

LANGBEIN W.B., 1949: Annual floods and the partialduration flood series. Transactions, AGU 30, 6, p. 879-881.

MADSEN H., RASMUSSEN P.F., ROSBJERG D., 1997: Comparison of annual maximum series and partial duration series for modelling extreme hydrologic events. Water Resour. Res., 33, p. 747-757.
MARES C., MARES I., STANCIU A., 2009: Extreme value analysis in the Danube lower basin discharge time series in the twentieth century, Theor. Appl. Climatol., 95, 223-233.

MITKOVÁ V., PEKÁROVÁ P., KOHNOVÁ S., SZOLGAY J., 2003: Porovnanie odhadov návrhových maximálnych prietokov pri rôznom spôsobe zostavenia štatistického radu kulminačných prietokov v profile Dunaj Bratislava. Sborník př́spěvků z Workshopu „Extrémní hydrologcké jevy v povodích", Praha, str. 61-70.

NORTH M., 1980: Time-dependent stochastic models of flood. ASCE J. Hydraul. Div., 106, p. 649-665.

ONOZ B., BAYZAIT M., 2001: Effect of the occurrence process of the peaks over threshold on the flood estimation. J. Hydrol., 244, p. 86-96.

RAO A.R., HAMED K.H., 2000: Flood frequency analysis. CRC Press LLC, N. W. Corporate Blvd., Boca Raton, Florida.

RASMUSSEN P.F., ROSBJERG D., 1991 a: Evaluation of risk concepts in partial duration series. Stochastic Hydrol. Hydraul., 5, p. 1-16.

RASMUSSEN P.F., ROSBJERG D., 1991 b: Prediction uncertainty in seasonal partial duration series. Stochastic Hydrol. Hydraul., 1, p. 3-16.

RASMUSSEN P.F., ROSBJERG D., 1989: Risk estimation in partial duration series. Water Resour. Res., 25, p. 2319 -2330 .

ROSBJERG D., 1977: Returns periods of hydrological events. Nordic Hydrol., 8, 57-61.

ROSBJERG D., 1985: Estimation in partial duration series with independent peak values. J. Hydrol., 76, p. 183-195.

ROSBJERG D., RASMUSSEN P.F, MADSEN H., 1991: Modelling of exceedances in partial duration series. Proc. Int. Hydrol. and Water Resour. Symp. Perth, p. 117-760.

ROSBJERG D., 1987: Partial duration series with Lognormal distributed peak values. In: Hydrological Frequency Modelling. V.P. Singh. (ed.). Reidel, p. 117-129.

ROSBJERG D., MADSEN H, RASMUSSEN P.F., 1992 Prediction in partial duration series with generalized Pareto distributed exceedances. Water Resour Res., 28, p. 3001-3010 .

SVOBODA A., PEKÁROVÁ P., MIKLÁNEK P., 2000: Flood hydrology of Danube between Devín and Nagymaros. SVHÚH SAV, pp. 96.

SZOLGAY J., KOHNOVÁ S., HLAVČOVÁ K., 2003: Ilustrácia neistoty určovania N-ročných maximálnych prietokov Dunaja v Bratislave. Konferencia $\mathrm{s}$ medzinárodnou účast'ou „Ochrana pred povodňami a bezpečnost' vodných stavieb." Bratislava, s. 7-12.

SHANE R. M., LYNN W.R., 1964: Mathematical model for flood risk analysis. ASCE J. Hydraul. Div., 90, 1-20.

TODAROVIČ P., 1970: On some problems involving random number of random variables. Ann. Math. Statistics, Vol. 41, No. 3, p. 1059-1063.

VUKMIROVIČ V., PETROVIČ J., 1995: Flood flow analysis using renewal processes. Grupe AMHY, Seminar annual.

ZATKALÍK G., 1965: The 1965 Danube flood. (In Slovak). Vodní hospodářství, 12, 519-526.

ZEELENHASIC E., 1970:Theoretical probability distributions for flood peaks. Hydrology Paper No. 42, Colorado State University, Fort Collins, Co.

WANG Q.J., 1991:The POT model described by the generalized Pareto distribution with Poisson arrayal rate. J. Hydrol., 129 , p. $263-280$ 
Received 4 May 2009

Accepted 10 March 2010

\section{ANALÝZA EXTRÉMNYCH HYDROLOGICKÝCH SITUÁCIÍ NA DUNAJI VYUŽITÍM METÓDY POT}

\section{Veronika Bačová-Mitková, Milan Onderka}

K hodnoteniu metód určovania $N$-ročných prietokov viedol najmä značný vývoj poznatkov v oblasti ich určovania (nové typy rozdelenia, regionalizácia), ako aj výskyt významných povodní $\mathrm{v}$ posledných rokoch a aj predíženie pozorovaných radov.

Metódy odhadu $N$-ročných prietokov z ročných maxím vychádzajú len z jednej maximálnej hodnoty prietoku v roku. Metóda POT však zahŕňa do analýz všetky hodnoty prietokov nad zvolenú prahovú hodnotu, čím sa do analýz dostávajú prietoky druhé alebo tretie v poradí svojou vel'kost'ou, ktoré ale môžu byt' väčšie ako maximálne prietoky $\mathrm{v}$ iných rokoch. $\mathrm{V}$ danom príspevku boli teda porovnané rôzne prístupy $\mathrm{k}$ určeniu $N$-ročných prietokov Dunaja vo vybraných staniciach. Porovnané boli POT metóda podla Vukmiroviča a Petrovičovej (1995), štandardná metóda maximálnych ročných prietokov, logaritmicko-normálne rozdelenie a Pearsonovo rozdelenie III. typu. Analýza bola aplikovaná na extrémne hydrologické udalosti na Dunaji v profiloch: Achleiten, Kienstock, Viedeň, Bratislava a Nagymaros počas obdobia 1931-1990. Boli spracované dostupné hydrologické údaje a vytvorená vhodná databáza pozorovaných prietokov na Dunaji vo zvolených staniciach. Pre analýzu boli použité vybrané ročné maximálne prietoky, ako aj priemerné denné hodnoty prietokov nad zvolenou hranicou prietoku Qpot (POT). V d'alšom kroku boli aplikované už vybrané metódy odhadu prietokov s rôznou dobou opakovania na Dunaji v staniciach Achleiten, Kienstock, Viedeň, Bratislava a Nagymaros. V závere sme porovnali a zhodnotili získané výsledky odhadov.

Dížka spracovávaného radu má tiež, okrem výberu teoretického rozdelenia pravdepodobnosti, významný vplyv na odhad $N$-ročných prietokov. Preto druhým ciel'om príspevku bolo analyzovat' vplyv zmeny dížky časového radu na odhad $N$-ročných prietokov. V práci bol 60-ročný časový rad údajov skrátený na 40-, 20a 10-ročné rady zo začiatku a konca pozorovaného obdobia. V závere boli porovnané výsledky vplyvu zmeny dížky časového radu na odhad prietokov s rôznou dobou opakovania nami zvolenými metódami odhadu. Pri časovom rade 60 rokov metóda POT dávala najvyššie hodnoty prietokov pre stanice Bratislava a Viedeň. Pri skrátení dĺžky časového radu na 40, 20 a 10 rokov dávala metóda POT vyššie alebo porovnatel'né odhady $Q_{N}$ pre stanice Kienstock, Viedeň a Bratislava (obr. 6a)-b) a 7a)b)), odhad pre stanicu Nagymaros dával najvyššie hodnoty $Q_{N}$ prietoku pre logaritmicko-normálne rozdelenie pre periódy zo začiatku pozorovaného obdobia.

Z výsledkov analýzy vyplýva, že metóda POT dáva pomerne dobré odhady $N$-ročných prietokov aj pre krátke časové rady údajov.

\section{Zoznam symbolov}

$v \quad-$ počet vrcholov $\mathrm{v}$ roku,

$\mathrm{Z}_{v} \quad$ - prekročenie prietoku $\left[\mathrm{m}^{3} \mathrm{~s}^{-1}\right]$,

$\chi(t)$ - výskyt prietoku v čase $\left[\mathrm{m}^{3} \mathrm{~s}^{-1}\right]$,

$x_{B} \quad$ - prahová hodnota prietoku $\left[\mathrm{m}^{3} \mathrm{~s}^{-1}\right]$,

$x \quad$ - hodnota prietoku (maximálny prietok) $\left[\mathrm{m}^{3} \mathrm{~s}^{-1}\right]$,

$\lambda(t, v)$ - funkcia intenzity,

$\eta \quad-$ celkový počet vrcholov,

$t \quad-$ čas [hod],

$\Delta t \quad$ c časový rozdiel výskytu počtu vrcholov [hod],

$z \quad$ - premenná (vel'kost' prekročeného prietoku nad prahovou hodnotou) $\left[\mathrm{m}^{3} \mathrm{~s}^{-1}\right]$,

$\mu, \beta, \alpha$ - parametre rozdelenia,

$F_{n}(x)$ - empirická distribučná funkcia,

$F(x)$ - teoretická distribučná funkcia,

Cv - koeficient variácie,

Cs - koeficient asymetrie,

$P$ - pravdepodobnost' prekročenia [\%],

$H(z)$ - funkcia hustoty,

$R(x)$ - doba opakovania [roky]. 